\title{
UM ANO ENTRE OS HUMANOS: RiCARDO AlEIXO E A ETNOGRAFIA DO HUMANISMO
}

http://dx.doi.org/10.11606/issn.2237-1184.v0i34p198-225

Marcos Natali ${ }^{1}$

RESUMO

$\mathrm{O}$ artigo apresenta uma leitura do poema "O peixe não segura a mão de ninguém", publicado por Ricardo Aleixo no livro Modelos vivos (2010). Como se trata de um poema preocupado com a taxonomia dos seres vivos, a leitura examina como a categoria do humano depende da hierarquização dos seres. Revisitando a relação entre a noção de humano e o racismo, o texto entrevê, nesse e em alguns outros poemas de Aleixo, uma apreciação crítica do humanismo. $\mathrm{O}$ trabalho termina com leituras de três textos críticos - de Sylvia Wynter, Zakiyyah Iman Jackson e Kate Manne - que, de diferentes maneiras, tensionam o pensamento humanista, em particular as hipóteses de que a exclusão do outro da categoria do humano seria condição necessária para a prática da violência e que, consequentemente, a inclusão na humanidade seria um passo indispensável e confiável em direção ao fim da violência racista.

\section{ABSTRACT}

The paper proposes a reading of the poem "O peixe não segura a mão de ninguém", published by Ricardo Aleixo in the volume Modelos vivos (2010). Since the poem is concerned with the taxonomy of living beings, the discussion examines the category of the human and its dependence on a hierarchy of beings, particularly with regard to racism, finding in this poem and others by Aleixo a critical appreciation of humanism. The paper ends with readings of three texts - by Sylvia Wynter, Zakiyyah Iman Jackson, and Kate Manne - that, in different ways, pressure humanist thought, especially the hypotheses that the exclusion of the other from the category of the human is a necessary condition for the practice of violence and that, therefore, inclusion in humanity would be an indispensable and reliable step towards the end of racist violence.

\section{PALAVRAS-CHAVE:}

Ricardo Aleixo; Humanismo; Racismo.

\section{KEYWORDS}

Ricardo Aleixo; Humanism; Racism.

I Universidade de São Paulo, São Paulo, São Paulo, Brasil. 
Meu pai viu Casablanca três vezes (duas no cinema e uma na TV). Meu avô trabalhou na boca da mina. Meu bisavô foi, no mínimo, escravo de confiança.

“Álbum de família", Ricardo Aleixo

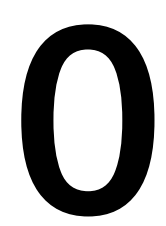

olhar percorre a página até o final do primeiro verso, onde o número flutua, sem referente claro, até chegar ao verso seguinte, que esclarece que, das três exibições do filme acompanhadas pelo pai, duas foram no cinema (ALEIXO, 2018, p. 46), só uma na televisão. Prosseguindo com a descida, degrau a degrau, verso a verso, numa espécie de contagem regressiva - três, duas, uma... - , sabe-se que o fim do poema está próximo. É a primeira coisa que se nota na página, afinal: são apenas quatro versos, não mais. Enquanto isso, enquanto descemos, o poema parece fazer movimento contrário, escalando a genealogia familiar: depois do pai, o avô, anunciado no segundo verso, mas caracterizado apenas no terceiro, no qual ele será definido não pelo gosto ou pela predileção cultural, como acontecera com o pai, mas por seu trabalho, nas minas. Chega-se finalmente ao bisavô, em verso que repete a estrutura dos anteriores, suspendendo mais uma vez o complemento, gerando a expectativa de que no próximo verso a frase será concluída, com a extensão da história familiar indicando, como nos dois casos anteriores, uma particularidade do antepassado. O ritmo ameno dos versos, a presença da rima e da repetição, o paralelismo no começo das três frases, cada uma enfatizando a relação pessoal e afetiva com o enunciador (meu pai, meu avô, meu bisavô...), os ecos sonoros (a "mina" reaparecendo, transformada, em "mínimo"): tudo sugere que no último verso haverá a continuação do relato da genealogia familiar, esperança só aguçada pela pausa imposta pela vírgula depois do verbo que abre o último verso.

E então o fluxo é interrompido, e de tal forma que o abalo provocado pela irrupção final não vai deixar em pé qualquer uma das convenções dos gêneros associados às memórias familiares. O poema, ao se voltar para o passado, se depara com a escravidão. Era a isso que ele nos conduzia, era esse o seu horizonte, e, desde o início, tudo nos versos - o ritmo, a sonoridade, as referências aos antepassados - nos levava ao encontro com o horror da escravidão. O trabalho do avô na mineração, o pai na sala de cinema ou diante da televisão, sua fascinação por Casablanca, o exercício de rememoração daquele que narra: tudo precisará voltar a ser lido, nada permanecerá intocado pelo corte no verso, e na genealogia familiar, ambos

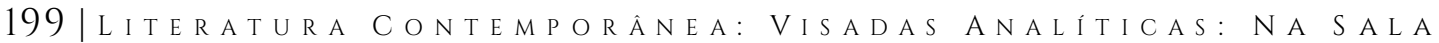
D E A U L A 
causados pela aparição da escravidão. Ambos - poema e genealogia - se encerram ali naquele verso, e é mesmo difícil imaginar outro, depois dele, difícil imaginar que o poema continuasse - assim como é exercício difícil continuar a descrição da ascendência familiar, a escravização tendo, entre seus princípios e como uma de suas práticas, a negação dos laços familiares e da filiação dos escravizados. Também é difícil pensar que possa ser outro o rumo, outro o tema, para uma reflexão sobre o poema, ou sobre a história do país de que ele trata, após o impacto do fim do poema. Questões de valor e prestígio, tão importantes no estudo da literatura, são aqui violentamente ressignificadas, ironizadas pelo poema com a menção nesse último verso às hierarquizações cruéis existentes no interior dos ambientes escravistas, uns sendo colocados contra outros.

Esse é o legado do país e de sua poesia; é esse o seu arquivo e sua história. Também parece ser o seu presente, pois o poeta, ao sair a caminhar pela cidade - "Conheço a cidade/ como a sola do meu pé", diz outro poema de Ricardo Aleixo (2018, p. 150) -, repetindo cena arquetípica da poesia moderna que é importante para a formação da imagem daquilo que faz o poeta na modernidade, o que encontra, além de buracos, ônibus, carros, dejetos na calçada, dobras, retas e curvas, é "outros humanos polícias". Mesmo flanando pelas ruas, então, precisará manter "espírito e corpo prontos", na esperança de conseguir evitar a ameaça. Tanto o álbum de família quanto as ruas da cidade serão uma espécie de "Labirinto", título desse poema, um espaço do qual dificilmente se sai; e dentro dele estará a polícia, que, junto a outras figuras, representa a possibilidade permanente da agressão gratuita, sem razão ou justificativa, a possibilidade constante da morte, na reencenação pública que serve para comprovar a continuidade da lógica escravista (cf. PATTERSON, 2008). Assim, se é comum na tradição associar a poesia de modo amplo à noção de encontro, o passeio pela biblioteca da poesia brasileira destacará nessa experiência a convivência com a possibilidade de topar, a qualquer momento, com a violência. ${ }^{1}$

Ainda que a história que se queira contar seja outra, e mesmo quando o que se deseja é escrever contra o arquivo, resta o fato de o próprio arquivo ter sido constituído pela violência da escravização. Na historização da família e na reconstrução da genealogia, a pesquisa - sobre a vida do pai, por exemplo - será penosa, pois a prosa da contrainsurgência só tem interesse em registrar no arquivo as vidas no momento em que precisam ser reprimidas (cf. GUHA, 1988), e o pai não teria despertado o interesse do olhar repressor:

\footnotetext{
${ }^{1}$ Analisando alguns poemas de Ricardo Aleixo, Luciany Aparecida Alves Santos vai lê-los em paralelo a trechos do Diário intimo de Lima Barreto, páginas nas quais, quase 100 anos antes da publicação de "Labirinto", já são narrados encontros tensos nas ruas com soldados e policiais (SANTOS, 2015, p. 197-8).
}

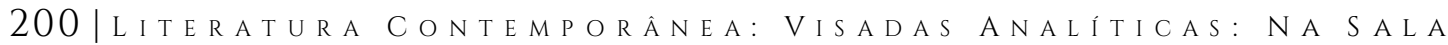
D E A U L A 
[...] Você procura o homem velho que é

seu pai nas fotografias

que ilustram reportagens

nos jornais e revistas

e não o

encontra. Porque ele

é um homem

absolutamente comum

e homens

absolutamente comuns

não têm suas fotos publicadas

nas páginas de jornais $\mathrm{e}$

revistas

senão quando cometem algum crime.

Seu pai é honesto. (ALEIXO, 2018, p. 17-22)

Passo agora a uma leitura mais demorada de outro poema de Ricardo Aleixo, publicado primeiro no livro Modelos vivos, em 2010, para depois ser reeditado, em 2018, na antologia Pesado demais para a ventania.

“O peixe não segura a mão de ninguém"

O quarto é um peixe. Três não são peixes. São homens, isto se vê. Nenhum dos três que não são peixes foi pescado

pelos demais. Desconfio que o peixe foi pescado por um outro que não aparece na fotografia. Um homem. Com

uma câmera fotográfica. O peixe está morto. Não compreende que foi fotografado, morto como parece estar. No tempo em

que foi batida a fotografia, todos, menos o peixe, estavam vivos. O menor de todos ainda não fizera filhos em ninguém. Era,

ele próprio, filho. Um dos dois feitos por um dos outros dois. Que também eram filhos. De pais que não apareciam na

fotografia. E que também eram pais de filhos fora da fotografia. O que segura o peixe era pai do menino de quem o outro dos 
dois mais velhos segurava a mão. O menor de todos (menor até do que o peixe dado como morto, porque ostentado como um

troféu e suspenso por um anzol) tinha uma irmã. Mesmo não aparecendo na fotografia, a irmã do menino era filha do que

segurava o peixe. Não se sabe se o peixe, que também era filho, tinha filhos. Nem se o outro homem, o que segurava a mão do

filho do homem que segurava o peixe morto, tinha seus próprios filhos, crescidos de sua própria porra. O peixe foi comido por

alguém que não aparece na fotografia. E por sua família. Não a do

peixe, mas a de quem o fotografou. A família do pai que segurava

o peixe não comeu nem a mais minúscula lasca do peixe. A família

do outro homem, se é certo que ele tinha uma, tampouco provou

do peixe. Dos quatro que aparecem na fotografia, nenhum sorri. Nem diz palavra. O peixe tem a boca aberta. A fotografia comprova

o que se diz: que peixes morrem pela boca. As bocas dos três que não são peixes estão cerradas. Por elas não escorrem nem sorrisos

nem palavras. São três bocas silenciosas. Três silêncios de ouro. Quatro, com o do peixe. Que está com a boca aberta. Cinco, com

o do homem que fez a fotografia. A sombra dele se projeta sobre o corpo do homem que segura a mão do filho do homem que segura

o peixe. O peixe, decerto porque está morto, não segura a mão de ninguém. Dos homens, o menor de todos é o único que escreverá

um dia sobre o tempo longínquo em que se posava para fotografias

com um peixe morto suspenso por um anzol. O peixe está alheio a

tudo o que seu olhar morto já não é capaz de ver. Peixes não escre-

vem. A maioria dos homens também não. Alguns homens escrevem

sobre peixes e homens que pescam peixes para exibi-los como troféus. Uma fotografia é uma forma de pescar pessoas, pensa o 
menino. Numa fotografia todos parecem mortos, pensará ainda

o

menino quando já for, não mais um menino, mas o pai de algum

menino ou de alguma menina. Um dos quatro na fotografia talvez

seja eu. Eu não sou o/um peixe. Ele, o peixe, já havia sido pescado

e exibido como um troféu naquele tempo. Eu não sou um troféu. Nem sou os outros dois que aparecem na fotografia. Nem é minha a

sombra que repousa para sempre sobre o que parece ser o mais velho dos que aparecem com nitidez na fotografia. E que nunca

serão totalmente peixes, mesmo depois de mortos. À mãe dos filhos peixes, minha mãe, aprendi que só devo pedir, agora, quando

já não sou o menor de todos, o seguinte benefício: que peixe morto algum se pareça comigo quando a morte vier me pescar. (ALEIXO, 2010, p. 147-9)

Se parece inegável que o que chega primeiro é o título - antes até que o poema em si tenha começado -, o que encontramos no título, nesse ou em qualquer outro, é que ele também chega tarde, e é posterior a uma série de outros elementos: o nome do autor, que se sabe que é alguém que escreve poemas (embora componha também outros tipos de textos e obras, incluindo performances musicais e de dança); o fato de que o título aparece dentro de um livro de poemas, ao lado de textos que parecem poemas (mas não sempre, e nem todos); nosso conhecimento de outros poemas; nossa compreensão da ideia mesma de poema, incluindo a diferença entre verso e prosa, diferença que afeta desde o início a experiência de leitura (sua velocidade, suas formas de atenção, sua avaliação das estranhezas do texto). Nesse caso, há um início que não anuncia ou explica a que veio, dispensando qualquer gesto introdutório; o poema parece cair sobre nós, vindo de algum lugar que não sabemos qual é. Se com outros tipos de texto costuma ser mais fácil encontrar uma resposta para a pergunta a respeito de sua motivação, o poema, escreve Jean-Luc Nancy, "é uma máquina destinada a suscitar a interrogação: por que será que isso foi escrito?". Enquanto outros textos parecem responder a uma demanda, o esforço do poema é justamente por suscitar a pergunta por sua razão de ser (NANCY; LALUCQ, 2021, p. 122). Por qual razão isso terá sido escrito, então, mas também: qual o sentido desse texto não querer me dizer, como começo de conversa, numa introdução ou um prefácio de algum tipo, a sua razão? 
É verdade que a forma do título lembra uma afirmação, ainda que estranha e imprecisa, e complicada pela dupla negação. A frase parece dizer respeito a um peixe, e à possibilidade de que ele segure as mãos de outros - peixes ou não-peixes, não sabemos. Fosse indefinido o artigo, e o título "Um peixe não segura a mão de ninguém", entenderíamos que se trata de uma constatação generalizável a respeito da categoria dos peixes: um peixe, qualquer um, em qualquer situação, nunca age assim. Como no título o que identifica o peixe é um artigo definido, o poema de novo remete a um conhecimento prévio. Como parte de um conjunto qualquer, composto também por outros seres, peixes ou não, o peixe, esse peixe, não está segurando a mão de outros, ao menos não neste momento, pois a construção do título não proíbe que ele venha a fazê-lo no futuro, nem recusa a possibilidade de que já o tenha feito antes. Não é obrigatório que seja assim, mas há ao menos a sugestão, que aumentaria a relevância da afirmação, de que nesse aspecto há um contraste entre o peixe e outros componentes do grupo, esses, sim, de mãos dadas. A tradução nesse caso seria que, à diferença de outros, o peixe não segura a mão de ninguém. Com esse conjunto de elementos, que inclui a presença de um animal, o título estabelece certo tom menor para o poema, reforçado pelo aspecto descritivo que insinua se tratar de um relato incontroverso e sem transcendência.

Haverá ao longo do poema pouco a apontar em termos de "linguagem poética", se pensarmos no que convencionalmente se associa àquilo que pode acontecer com a língua em poemas - embora não apenas neles, o que é um problema teórico importante, como também o é o fato de que o poema pode não ter qualquer um dos elementos que costumam ser chamados de poéticos. Nesse poema, praticamente não haverá rimas, assonâncias ou aliterações. O que há, e é imediatamente evidente para a leitora, é a distribuição dos versos em pares, pequenas unidades que vão organizar as frases do começo ao fim do poema, ao longo de mais de duas páginas, nas duas edições. O arranjo dos versos numa série de dísticos é a lei aparentemente arbitrária que o poema estabelece para si, princípio encontrado também em poucos poemas do autor, e que aqui vai ser obedecido até o final, sem exceção; serão dois versos por estrofe, nem mais, nem menos: $2+2+2 \ldots$, até chegar a 52. Para manter a fidelidade à regra, procedimentos de diferentes tipos serão utilizados, incluindo o corte de frases e até de palavras, definindo para os versos uma extensão semelhante, mas não idêntica.

A arbitrariedade da lei que organiza o poema - por que dois versos e não três? - atravessará o texto de várias maneiras, incluindo, como já sugerido, na pergunta sobre o que decreta que isso é um poema, e não outra coisa. Embora a lógica da construção lembre o acúmulo e a soma, o que a sequência produz, mais do que uma simples expansão, é a

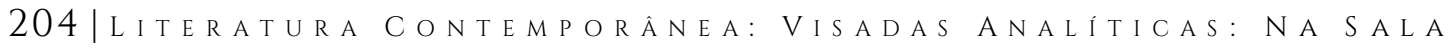
D E A U L A 
desestabilização da ideia de que há um princípio ou uma essência imutável capaz de definir os limites do conjunto, um princípio que garantiria o pertencimento das partes ao todo que é o grupo, como se vê na seguinte sequência, na qual os limites se desfazem para logo em seguida se recompor em outros termos: "São três bocas silenciosas. Três silêncios de ouro./ Quatro, com o do peixe. Que está com a boca aberta. Cinco, com// o do homem que fez a fotografia." Após o alargamento, passando do três ao quatro ao cinco, volta-se à unidade mínima, em movimento de contração, que, por sua vez, também será provisório, desestabilizando qualquer equilíbrio: “O peixe, decerto porque está morto, não segura a mão de/ ninguém. Dos homens, o menor de todos é o único que escreverá// um dia".

"O quarto é um peixe": como o título, o primeiro verso do poema também vai enfocar o peixe, apontado como o quarto de uma série ainda desconhecida, uma ocorrência dentro de uma sequência cuja composição e natureza ignoramos. Desde suas primeiras palavras, o poema está preocupado com esse elemento estranho no grupo, aquele que, embora nomeado antes que os outros, e o único presente no título, é definido no começo como o último da série, o quarto de quatro. Efetivamente, logo aprenderemos também que, nesse agrupamento em que o peixe foi incluído, só ele é um peixe, enquanto os outros três "não são peixes. São homens".

Que os outros não são peixes, mas homens, é algo que "se vê", assegura o segundo verso, retomando a frase interrompida no final do primeiro. Quem é o sujeito desse olhar - olhar que é capaz de confirmar o pertencimento dos três (mas não dos quatro) à humanidade - ainda não há como saber, até porque nem sabemos bem o que está sendo visto (é uma cena com três homens, após uma pescaria, diante de uma testemunha qualquer?; por que isso seria assunto para um poema?). Tudo parece indicar, já nesse início, que se trata de uma investigação dos regimes de visibilidade, das condições que definem o visível e o invisível, da relação entre o visível e o dizível, da gramática que rege as relações entre o poder e a exibição.

A pergunta que se impõe é: se são quatro, mas um não é humano, que tipo de conjunto eles compõem? Qual categoria daria conta de nomear os quatro? O poema não responde, recusando-se a nomear o grupo e preservando para a questão a forma aberta da interrogação. A omissão deliberada chamava a atenção desde o início, onde o poema escolheu uma construção incomum para anunciar que "O quarto é um peixe". É como se, quando o poema (ou o poeta) chegou, o grupo já estivesse formado; é como se o gesto de delimitação e formação do grupo fosse anterior ao poema, e como se, na sua recusa a nomear o grupo, ou a repetir o nome atribuído a 
ele, o poema revelasse seu incômodo com a operação prévia de demarcação.

Já para a pergunta sobre o motivo da centralidade da visão haverá uma resposta na segunda estrofe, que menciona uma fotografia. É numa fotografia, então, que "se vê" que três são homens, o pertencimento à humanidade identificado com naturalidade, à primeira vista (premissa que o poema apresenta aqui para interrogar depois). Também nessa estrofe começamos a entender o sentido do artigo definido: é "o peixe" porque é esse peixe, o da foto, que está sendo apontado. Antes do poema, então, houve uma foto, e o assunto dos versos será, não a cena, propriamente, mas a fotografia. O tema é o que o poema vai fazer com essa foto, ou, de maneira mais ampla, o que pode um poema diante de uma foto, e como se desenrola o embate entre os dois.

Em Modelos vivos, um dos livros em que "O peixe não segura a mão de ninguém" foi publicado, há, ao longo do livro, o que parecem ser fragmentos de uma foto, espalhados pelas páginas do volume (no livro posterior, Pesado demais para a ventania, desaparece a fotografia). São oito fotos, ou recortes de fotos, cobrindo páginas inteiras de diferentes seções do livro, algumas retratando um menino e um peixe, além de partes dos corpos de dois homens. A serialidade, que imaginamos ausente da fotografia, mas não do cinema (paixão do pai em “Álbum de família”), é recuperada pelo poeta através dessa estrutura sequencial, o livro revelando pouco a pouco diferentes partes da foto, como a narrativa em série vai revelando aos poucos diferentes aspectos de uma história.
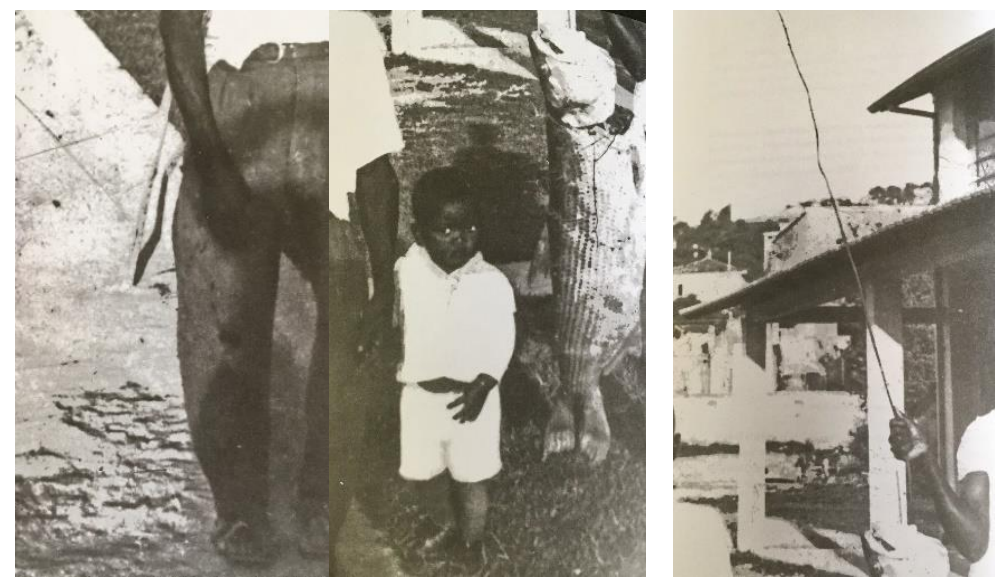

Fotografias reproduzidas no livro Modelos vivos. (ALEIXO, 2010, p. 2, p. 6, p. 154)

Será possível confirmar que se tratava mesmo de uma única foto, da qual os oito fragmentos foram recortados, apenas na última página do livro, depois do posfácio de José Maria Cançado, depois da página com a descrição das técnicas visuais utilizadas no livro, depois da nota biográfica 
e, o mais importante, depois do poema. ${ }^{3} \mathrm{O}$ poder que viria da anterioridade da foto é subvertido pela estrutura do livro, que recorta, desloca, descreve e comenta a imagem de tal forma que, quando finalmente chegarmos a ela, ressoará na fotografia tudo aquilo que já lemos, como se fosse ela uma legenda para o poema, e não o contrário, como se ela fosse um efeito do poema.

O que vai se delineando aos poucos nessas primeiras estrofes é que o alvo do poema é a violência da gramática visual que tornou possível uma fotografia como essa, o regime de visibilidade que gerou a foto. É relevante, nesse sentido, que não sejam quatro, como inicialmente se disse, as personagens do poema, mas cinco: além do peixe e dos três homens, o poema aludirá a alguém que, ainda que não apareça na fotografia (ou não plenamente), tem um papel decisivo na sua constituição. Foi esse outro "um homem", esclarece o poema - que capturou o peixe, é ele quem agora segura a câmera fotográfica, lançando sua sombra sobre os fotografados, detalhe que a fotografia também registrará. A pergunta pela identidade dos quatro seres captados pela imagem, questão que parecia metafísica, com isso é deslocada, destacando seu aspecto necessariamente relacional. À pergunta sobre o critério ou lei que teria definido que os quatro participantes pertenciam a um mesmo conjunto, conjunto no qual o peixe seria um entre quatro, responde-se agora que o grupo foi inventado pelo olhar de outro homem, auxiliado pela prótese que é a câmera fotográfica.

Se o poema dissera que era evidente que, dos quatro, três eram homens, ligando o dizível à aparência, a obviedade é abalada pela necessidade mesma de verbalizar e confirmar aquilo que seria autoevidente e incontestável. São homens, isso é inegável - é isso o que foi preciso afirmar, como se o poema antecipasse a dúvida. De algum lugar surgira um rumor a insinuar que, apesar das evidências, alguém duvidou da humanidade dos três, suscitando a necessidade de o poema assegurar que eles são, efetivamente, homens, e que isso devia estar claro para todos desde sempre. Incrementando o estranhamento que começa a caracterizar a descrição da cena, aclara-se que nenhum desses três homens foi "pescado// pelos demais". Mais uma vez, o fato de que é necessário fornecer o esclarecimento supõe em alguma medida a possibilidade de seu contrário: que homens - esses ou outros - são pescados por outros homens.

Assim, despontando atrás da sombra lançada pelo fotógrafo, surgindo por trás do corpo que segura a câmera, os versos dão forma poética a uma perspectiva que vai tensionar a taxonomia de que depende o mundo constituído pelo olhar da câmera. Ao destacar a "a sombra que repousa para sempre" sobre aqueles que estão na fotografia, o poema

\footnotetext{
${ }^{3}$ Reiterando o desejo materializado no livro, neste ensaio a exibição da foto também será adiada, acontecendo apenas após a leitura do poema.
}

207 Literatura Contemporânea: Visadas Analíticas: Na SAla D E A U L A 
nomeia a presença silenciosa do fotógrafo, que é parte da cena mesmo quando se coloca fora dela. Essa sombra, protestará o poeta, "não é minha", insistindo na diferença e explicitando a existência de um embate. O que é importante aqui é que, após o que parecia ser o encerramento da cena, após o fechamento do círculo, aparece mais um elemento, exigindo a reconceitualização, renomeação e reorganização do conjunto. ${ }^{4}$ Em outras palavras, os quatro seres da foto são vistos pelo fotógrafo, cuja sombra, como seu olhar, atravessa o limite entre o dentro e o fora. O fotógrafo e seu olhar se tornam parte daquilo cuja existência estariam simplesmente registrando de maneira imparcial. Entretanto, o fotógrafo que observava e, com sua sombra, nublava a cena é por sua vez visto, anos mais tarde, por outro, que é o poeta (que talvez tenha sido o menino), que também será, uma vez escrito o poema, lido por outros. Não se trata de uma cronologia: primeiro um, depois o outro, finalmente mais um. Cada cena já está atravessada e assombrada pela outra, a qual, por sua vez, está presente e ausente na cena "original". O fotógrafo, com sua sombra, com seu desejo, é parte da foto, como "sombra que repousa para sempre" sobre os fotografados. Nós, leitoras e leitores, também estamos desde sempre lá, no poema que surgiu e foi redigido tendo em vista nossa existência.

Se a fotografia fora o desejo de cristalização na imagem de um momento triunfal, secando no negativo o sangue capturado, o poema, com sua pulsão narrativa, transborda os limites estritos da moldura e apresenta com seus relatos especulações sobre o antes e o depois da captura. Isso acontece primeiro com os acenos a todos aqueles que não estão na foto. Como em "Álbum de família", aqui também se trata de reconhecer uma genealogia, tanto na nomeação dos antepassados ausentes - os homens da foto "também eram filhos. De pais que não apareciam na// fotografia" quanto na indicação de uma herdeira excluída da cena - "Mesmo não/ aparecendo na fotografia, a irmã do menino era filha do que// segurava o peixe". (No final do poema aparecerá a mãe, numa intervenção decisiva, à qual ainda chegaremos.)

O foco do poema volta a ser o peixe, impelindo-nos a pensá-lo com mais atenção: seu tamanho, seu peso, sua temperatura, seu cheiro, sua boca aberta, seus olhos e sua solidão, dado o lugar de exceção que ocupa dentro do conjunto. O que dizer do fato de que o olhar do poeta, ao se deparar com a foto, encontrando ou reencontrando aquela cena, se fixa justamente no peixe, aquele de quem, ainda que seja o único com a boca aberta, dificilmente se diria que tem um "lugar de fala"? "O peixe está morto", lemos na terceira estrofe, e "Não compreende/ que foi fotografado". Contudo, já no verso seguinte a morte, que parecia certa, é colocada em

\footnotetext{
${ }^{4}$ Posso apenas mencionar isso aqui, até como expressão do desejo de voltar ao tema, mas seria possível desenvolver, a partir desse ponto, a questão, crucial para a teoria literária e para a filosofia política, da relação entre a parte e o todo.
}

208|literatura Contemporânea: Visadas Analíticas: Na Sala D E A U L A 
questão: o peixe "parece estar" morto. Na mesma linha, mais adiante, a referência será não ao peixe morto, mas a um "peixe dado como morto". A morte passa de fato natural, que precisaria apenas ser confirmado pelo olhar, dada a evidência empírica, a acontecimento social controverso, dependente da interpretação. De repente, há ambivalência, pois é possível que exista diferença entre a aparência e a realidade do peixe, e de repente ressalta-se que alguém precisou declarar que o peixe estava morto. A crítica à certeza quanto à morte do peixe é significativa, e o poema voltará a ela em alguns trechos decisivos, inclusive nos versos finais. Em questão está a diferença entre morte social e morte física, distinção que permite que um ser senciente, ainda vivo, seja dado como morto. É nesse quadro que se tornaria aceitável que ele fosse exposto como troféu mesmo sem sua morte física, gerando a disputa, da qual o poema vai participar, a respeito da natureza dessa morte.

Uma construção frasal incomum - o peixe é "dado como morto, porque ostentado como um/ / troféu e suspenso por um anzol" - permite até que se entenda que há uma relação de causalidade entre ser exibido como um troféu e ser considerado morto (e não uma relação de interdependência, no sentido de que só é ostentado como troféu aquele que já está morto). Que o ser senciente seja exibido a um público, apresentado como prova de poder e dominação, funciona como um atestado de óbito, criando a sua morte. Trata-se de um rito social conhecido, com convenções já familiares: após a pescaria bem-sucedida, segura-se o cadáver, o pescador de frente para a câmera, com um sorriso triunfal. No caso dessa foto, há uma dissonância em relação à gramática normativa cujo sentido se entenderá só depois: aqui ninguém sorri.

A narração feita pelo poema também vai se interessar pela história do peixe após a foto, uma história que vai indicar a existência de mais uma cisão dentro da categoria dos humanos. Aqueles que posam ao lado do peixe, que à primeira vista poderíamos imaginar que ostentavam o peixe como um troféu, na verdade não irão se alimentar dele. Estão lá como figurantes, sem consumar o ritual de dominação, o que será feito apenas "por// alguém que não aparece na fotografia. E por sua família", a do homem que detém a câmera e o poder. Já "A família do pai que segurava/ / o peixe não comeu nem a mais minúscula lasca do peixe", nem uma mínima porção do alimento. Do outro homem, aquele que dá sua mão ao menino, pouco se sabe, e o poema desconhece inclusive se ele tinha filhas ou filhos; contudo, quanto a esse aspecto o poema diz ter certeza: "A família/ do outro homem, se é certo que ele tinha uma, tampouco provou// do peixe". A razão não é dita, mas podemos imaginá-la, pois diz respeito mais uma vez aos critérios para a separação dos humanos. Ao introduzir uma diferença que aponta para hierarquias dentro da categoria do humano, o poema problematiza aquilo que antes parecia sugerir: afinal,

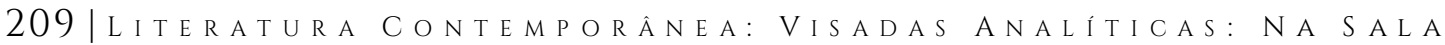
D E A U L A 
quem é troféu de quem? Quem segura e quem é segurado nessa cena? Os contornos do conjunto voltam a se desenhar, desta vez com os três, ainda que homens, como o fotógrafo, situados ao lado do peixe, capturados e exibidos como ele.

Os versos ainda vão sugerir outra possível ligação entre a morte e o peixe. O peixe é de novo incluído num conjunto criado pelo poema, que é agora a reunião de seres de cujas bocas "não escorrem nem sorrisos/ / nem palavras", grupo que é nesse momento composto por cinco, e não quatro. Dos cinco, um segura o peixe, outro segura a câmera, e dois se dão as mãos, enquanto o peixe, o peixe "não segura a mão de/ ninguém". Para explicar essa circunstância, o poema diz que não o faz "decerto porque está morto". Não é a natureza do peixe o que o impede de segurar a mão de outro, por mais que seja um lugar comum a alusão à mão como definidora da especificidade humana. Além da mão, é habitual na tradição humanista a referência ao domínio da escrita como um critério seguro para o estabelecimento da distinção entre humanos e inumanos. Inicialmente, o poema parece concordar, afirmando, um pouco adiante, que "Peixes não escre-/vem." Temos, aparentemente, um critério capaz de traçar a linha precisa que demarca a fronteira entre humanos e peixes, talvez até entre animais humanos e animais não-humanos: aqueles escrevem, esses não (embora nem isso se sustente, como se sabe). Entretanto, o poema continua, observando que "A maioria dos homens também não" escrevem, complicando a excepcionalidade humana. Nessa nova aproximação à questão do número, o que se coloca em relevo é o aspecto complexo e sinuoso de qualquer processo que busca definir o que é representativo e exemplar. A escrita, atividade apresentada como definidora da humanidade, condição para a diferenciação inequívoca entre humanos e não-humanos, é algo que, como se reconhece em seguida, a maioria das pessoas não faz. Efetivamente, de todos que aparecem na foto, só o menino escreverá sobre a cena, situada agora num "tempo longínquo em que se posava para fotografias/ com um peixe morto suspenso por um anzol" (ainda veremos que é duvidoso que tenha ocorrido de fato o abandono ou a superação desse tempo em que a exposição da morte era um ritual aceitável).

Além da escrita, outra atividade será identificada como exclusiva aos homens, mas também será limitada a alguns deles. A referência é, neste caso, à subcategoria de "homens que pescam peixes para exibi-los como/ troféus". Note-se que, segundo o verso, o objetivo da pesca é desde o início o espetáculo. Se a atividade torna aquele que participam dela mais ou menos humanos, mais ou menos representativos e exemplares da humanidade, é uma questão importante, com consequências de muitos tipos, ecoando a pergunta formulada em outro texto de Aleixo: "Humanos 
que matam humanos são inumanos, desumanos, humanos-feras ou apenas demasiado humanos?" (ALEIXO, 2018, p. 190).

Em meio à reflexão sobre a escrita, volta a hipótese de que há semelhanças entre o gesto de alguém que segura um peixe e o de quem segura uma câmera: "Alguns homens escrevem// sobre peixes e homens que pescam peixes para exibi-los como/ troféus. Uma fotografia é uma forma de pescar pessoas, pensa o// menino." No outro polo, no outro extremo da vara ou da câmera, há uma analogia possível entre as situações do peixe, pescado, morto e exposto, e os homens, capturados pela máquina fotográfica. (Quem decidiu tomar a foto? Quem recomendou aquele lugar, aquela pose? Por que ninguém sorri?) "Numa fotografia", observa o poema, "todos parecem mortos.", em associação entre fotografar (pessoas) e pescar (peixes) feita pelo menino, como esclarece o poema, embora não esteja claro quando isso teria ocorrido - se durante o próprio episódio, de que o menino participa como objeto do fotógrafo, ou depois, ao se lembrar dele. A ambivalência é efeito da peculiar maleabilidade do conceito de menino, pois, ao contrário do pertencimento à categoria de peixe, imaginase que seja possível deixar a infância, deixar de ser criança, sem que isso implique uma mudança na identidade do indivíduo (é possível imaginar um adulto dizendo "eu sou o menino da foto"). Com efeito, no próximo verso a duplicidade do termo será explicitada, pois "menino" será ao mesmo tempo aquilo que se continua a ser e aquilo que não se é mais: "Numa fotografia todos parecem mortos, pensará ainda o/ menino quando já for, não mais um menino, mas o pai de algum// menino ou de alguma menina."

Se o homem é e não é o menino, e o poema não sente necessidade de decretar aí limites claros, é diferente sua postura em relação à diferença entre os homens e o peixe. Quanto a isso o poema irá se posicionar de maneira enfática, adotando um tom inédito para ele. É de tal ordem a transmutação dos versos nessas quatro estrofes finais, tão dramática sua mudança de tom, que é como se ali entrássemos em outro poema, como se de dentro do poema surgisse outro poema, diferente daquele visto nas primeiras 22 estrofes, que agora precisam ser relidas como uma preparação para esse giro final. Irrompe aí pela primeira vez o pronome da primeira pessoa do singular, com a apresentação de uma negação categórica e categorial que destoa do timbre descritivo, distanciado e neutro da linguagem do poema até então: "Eu não sou um troféu". ${ }^{5}$

\footnotetext{
${ }^{5}$ Onde é possível escutar ecos de "Meu negro", texto escolhido para fechar a antologia Pesado demais para a ventania: "Eu não nasci negro. Não sou negro todos os momentos do dia. Sou negro apenas quando querem que eu seja negro. Nos momentos em que não sou só negro sou alguém tão sem rumo quanto o mais sem rumo dos brancos. Eu não sou apenas o que você pensa que eu sou." (ALEIXO, 2018, p. 194-5).
}

211 Literatura Contemporânea: Visadas Analíticas: Na SAla de A U L A 
Depois de tantos versos detalhando, com cuidado e paciência, as circunstâncias da cena construída pela cerimônia fotográfica, após tanto tempo dedicado aos diferentes personagens - o homem mais novo, $\mathrm{o}$ homem mais velho, o peixe, o menino, o homem com a câmera -, eclode uma voz insurgente que reivindica o direito à autodefinição, recusando o lugar que, sem a revolta, lhe seria reservado naquele espetáculo. Trata-se de uma resposta ao olhar e ao dispositivo, invertendo o movimento em curso e definindo como objeto de análise a perspectiva etnográfica que objetifica e congela, remetendo, nessa imagem como em tantas outras, à tradição das artes visuais coloniais. "Não sou um troféu": é angustiante que a afirmação precise ser feita, explicando tanto o seu volume quanto a necessidade da repetição. No contexto da cena colonialista, a declaração equivale à afirmação da diferença em relação ao animal não-humano, algo que o poema também fará explicitamente, numa frase que conta com a presença inusual de dois artigos simultaneamente: "Eu não sou o/um peixe". A sobreposição força a interrupção da leitura fluida, exigindo a repetição da frase, mas elimina a possibilidade da dúvida: não sou esse peixe, o peixe específico que aparece na foto, mas tampouco sou outro peixe qualquer; isso porque não sou nem peixe, nem troféu (pelo menos quando um for associado ao outro, como é nesse contexto). Dos outros dois homens que aparecem na foto também se dirá, nessas estrofes derradeiras, que não são peixes, ou melhor, em fórmula mais nuançada, e mais aterrorizante: "nunca// serão totalmente peixes". Em outras palavras, ainda que venha a acontecer de eles serem dados como peixes, ainda que eles venham a ser capturados, por câmera ou anzol, ainda que venham a ser vítimas da violência que os identifica como matáveis - protesta agora esse $e u$ que tomou conta do poema -, nem nesses casos terão se tornado "totalmente peixes", asseverando a inevitabilidade do fracasso da empresa que tenta reduzir pessoas ao inumano. Evitar que os dois homens e o menino sejam vistos como "peixes", definidos aqui como aqueles que são exibidos como troféus, será a principal tarefa a que se dedicará o poema, parte agora de uma espécie de motim poético. ${ }^{6}$

Até aqui não houve, nesta minha leitura, menção ao modo como opera no poema o gênero masculino, esse substituto metonímico da humanidade na linguagem patriarcal. No poema a questão não é simples, inclusive porque também ela, como todo o resto, precisaria ser pensada tendo em vista o modo como a negação da paternidade aos escravizados é parte fundamental da violência objetificadora de sociedades escravocratas. Os personagens do episódio são todos homens, com exceção do peixe, mas é de "homens" que se fala também quando se quer apontar para uma

\footnotetext{
${ }^{6}$ Para outro motim na poesia brasileira contemporânea, ver "Motim", de Edimilson de Almeida Pereira, poema que observa que "A espera, quando se trama,/ é faca/ espessa" (2019, p.32).
}

212 lliteratura Contemporanea: Visadas analíticas: Na Sala DE A U L A 
categoria maior, além do poema e da cena, como se esses representassem também a humanidade (lemos que "A maioria dos homens" não escreve, que "Alguns homens escrevem sobre peixes e homens que pescam peixes para exibi-los como troféus"). Entretanto, a inflexão que se dá nas estrofes decisivas, que aqui está sendo chamada de insurgência da voz poética, coincide com a incorporação ao poema de figura nova, a da mãe, antes ausente, como ausente esteve também do "Álbum de família". Nos últimos versos, a mãe, figura importante em outros poemas do autor, se torna a destinatária implícita do texto, agora transformado numa súplica:

[...] À mãe dos

filhos peixes, minha mãe, aprendi que só devo pedir, agora, quando

já não sou o menor de todos, o seguinte benefício: que peixe morto algum se pareça comigo quando a morte vier me pescar.

(ALEIXO, 2010, p. 149)

O que é preciso pedir a quem possa vir a cuidar dele após a morte (sua mãe, mas também Iemanjá, que sabe o que significa ter filhos peixes) é que se impeça que ele seja exibido como um troféu, como um peixe duplamente capturado, pelo anzol e pela câmera. Se existe o risco de ser dado como peixe, antes ou depois da morte, isto é, se está dada a possibilidade da morte social para a pessoa negra na sociedade racista, é ainda possível se insurgir contra a exibição que busca anular a diferença entre ele - menino e homem - e um peixe, contra sua classificação como "totalmente peixe". O poema termina com esse pedido, à espera de uma resposta da mãe, que ocupa agora lugar análogo ao nosso, como leitoras e leitores do poema.

Entre as respostas que precisariam ser dadas pela leitura do poema está a elaboração de alguma hipótese interpretativa para a seguinte dissonância: isso que se diz que não se faz a humanos, isso que é visto como tão condenável que se cogita chamar seus praticantes de "desumanos", foi e é feito a humanos neste país. A estrutura social brasileira é um instituto em que a possibilidade que o poema deseja evitar existe e se repetiu ao longo da história, tendo ocorrido com mulheres e homens que foram expostos e vendidos, como se fossem troféus, mercadorias. Nesse contexto, é preciso não só pensar e confrontar a violência antinegro e as variadas formas de violação que caracterizam o país, antes e depois da escravidão legal, mas a história do registro e representação dessa violência, isto é, a história da exibição e circulação dessa violência no mercado de imagens, como parte da construção de um imaginário que inventa e naturaliza a hierarquia que justifica a violência (ser exibido no espetáculo do poder é a autorização para ser dado como morto). A questão é entender não só as

213|Literatura CONTEMPORÂNEA: VISADAS ANALíticas: NA S A L A D E A U L A 
práticas de tortura existentes desde o período colonial, mas a razão de serem exibidas em praça pública e amplamente divulgadas; entender não apenas os linchamentos, mas a existência de fotos de linchamentos que circulavam como cartões postais.

Antes, assim como hoje, o aspecto crucial para entender a violência contra escravizados e a violência antinegro nas Américas é precisamente esse caráter público. Seu sentido sempre esteve vinculado à visibilidade, pois o que a violência comunica em primeiro lugar é a confirmação da disponibilidade de certos corpos para a violência, que será infligida com impunidade. Os incidentes recentes de assassinatos de pessoas negras no Brasil e nos Estados Unidos que se tornaram emblemáticos para movimentos sociais antirracistas não só foram gravados, mas, na maioria dos casos, ocorreram com o conhecimento de que estavam sendo filmados. O policial que em Minneapolis pressiona o pescoço de George Floyd com seu joelho durante nove minutos e 29 segundos sabe que está sendo filmado. Chega a olhar para uma das câmeras dos celulares que registram o episódio, sem que isso o faça hesitar ou querer ocultar o modo como está asfixiando um homem que, enquanto pode, suplicou por sua vida e chamou pela mãe. Aqueles que espancaram João Alberto Silveira Freitas no estacionamento de um supermercado em Porto Alegre até ele morrer sabem que estão sendo filmados e que há mais de uma testemunha ali. Quem deixou Miguel Otávio Santana da Silva sozinho no elevador do prédio residencial de Recife sabia que lá dentro havia câmeras de monitoramento.

Não é, então, que esses atos de violência aconteçam fora do espaço público, não é que se acredite que é necessário escondê-los da sociedade. O seu cenário é a rua, o estacionamento de um supermercado, o elevador de um edifício residencial. A sugestão aqui não é que violência, tortura e morte não aconteçam também em porões, becos e camburões, mas que a visibilidade e a transparência não são um impedimento à prática da violência. Mesmo nos episódios que ocorrem em lugares menos acessíveis, normalmente ainda haverá um elemento de exibição, as agressões acontecendo quase sempre diante de testemunhas, para as quais o espetáculo é realizado, em convite à sua cumplicidade e, eventualmente, à sua participação. Ao permanecer impune, mesmo quando inexistem dúvidas quanto aos fatos, mesmo quando existe o registro da violência, a morte física vem a confirmar o fato anterior, que era a morte social. Por isso é necessário que ela aconteça justamente como espetáculo público, pois só assim comprovará e reforçará um regime que inclui a conivência. (Nos Estados Unidos, durante sua longa história de violência antinegro, era comum que linchamentos acontecessem à beira de ferrovias, deixando depois os corpos à vista dos passageiros dos trens.) É nesse contexto que o poema se torna um espaço discursivo para o confronto, deslocando e

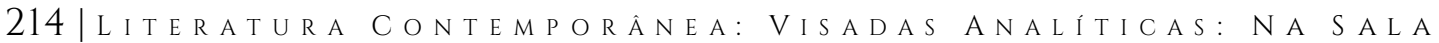
D E A U L A 
relendo práticas tradicionais de captura e registro de pessoas negras. Daí advêm também a importância da pergunta sobre quem, um dia, escreverá sobre a cena, e a razão de a fotografia aparecer no livro apenas depois de um poema ter sido escrito contra ela.

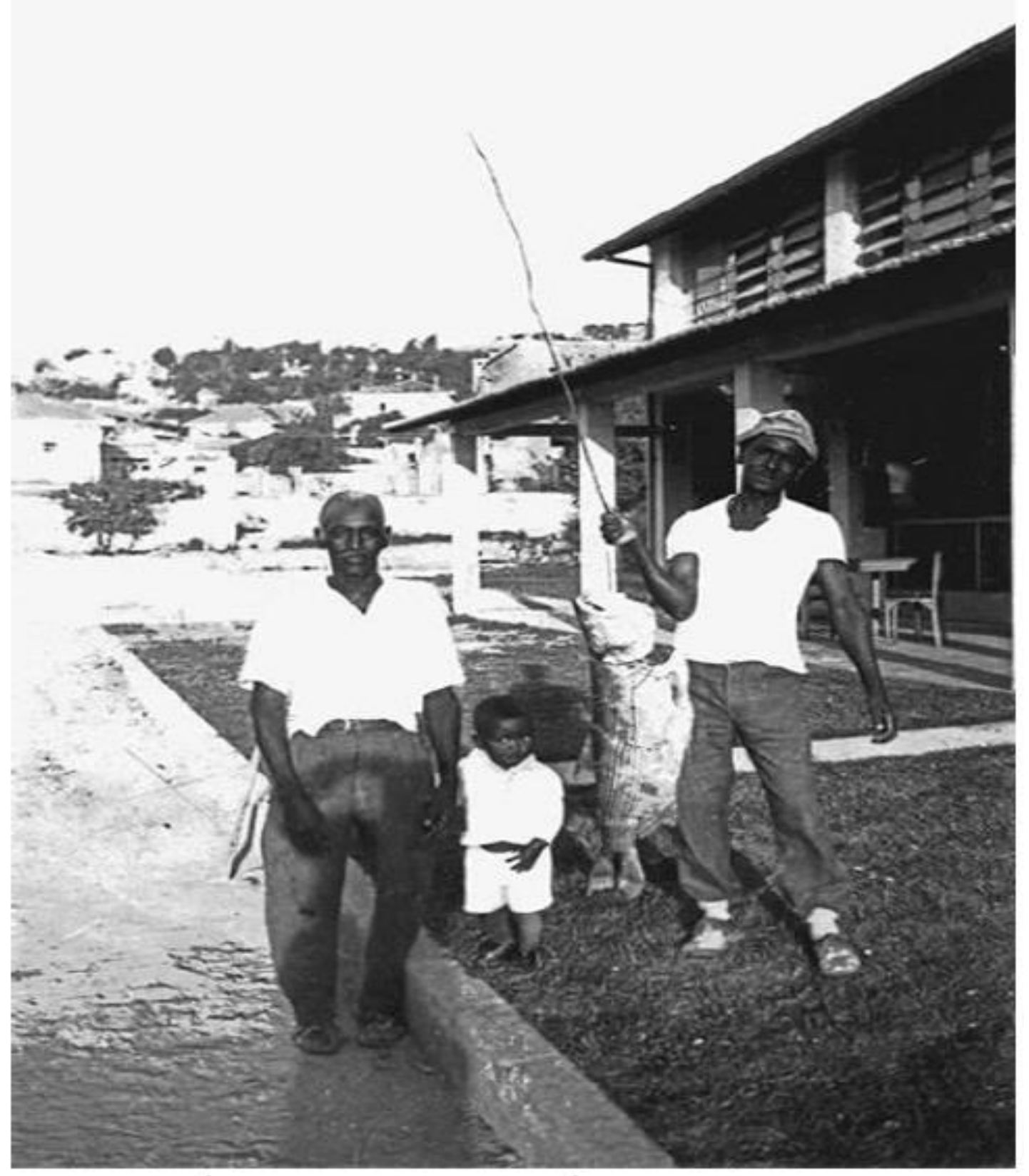

Fotografia reproduzida no livro Modelos vivos. (ALEIXO, 2010, p. 159) 
Em 2007, Ricardo Aleixo publicou uma versão do texto que depois seria publicado como o poema "O peixe não segura a mão de ninguém". Nessa ocasião, o texto, num único parágrafo ainda em prosa, mas já com o título que depois identificaria o poema, era identificado como "não-ficção" (ALEIXO, 2007, s.p.). Ainda que se considere que a cena retratada tenha ocorrido, ainda que se imagine que ela seja parte da história de vida do autor - nos dois textos, lê-se que "Um dos quatro na fotografia talvez seja eu" (grifo meu) -, o sentido referencial da cena e da foto não é simples. Segundo outro texto não ficcional, uma entrevista do autor concedida a Luciany Aparecida Alves Santos em 2014 (2015, p. 210), o que há de não ficção na foto, ou seja, sua "verdade", é, estranhamente, justamente o elemento ficcional. Ao falar de seu amor pela foto, lembrando que na imagem ele está próximo do pai, Aleixo adverte que ambos estão ali "numa situação ficcional, que é meu pai segurando um peixe. Meu pai, que não era um pescador, ele segurando um peixe enorme. Tem lá sua ironia, porque na nossa casa entrava pouquíssimo peixe" (p.210). Trata-se, continua, de

uma foto montada que põe em [xeque] o caráter de registro daquela fotografia. O que é que ela registra? Ela registra muito seguramente a encenação de uma relação de classe e raça. Um homem de classe média dono de uma máquina fotográfica, sócio de um clube, de classe média, que pede ao funcionário do clube para figurar [na] foto segurando um peixe, e ainda traz [o] amigo desse homem negro que também é negro e o filhinho desse homem. Então estamos ali naquela foto um pouco como [...] os homens e mulheres escravizados que aparecem no Debret, no Rugendas, [em] toda a iconografia sobre a escravidão no Brasil, no fotógrafo Marc Ferrez. Eu vejo essa foto um pouco como a simulação dessa situação em que quem fotografa registra a própria performance de dominação. (p. 210)

O escritor descreve então como compreende o poema que viria a escrever em resposta a essa performance de dominação: “o texto é a tentativa de uma performance de escapar, é a tentativa de escapar de uma situação de aprisionamento imagético e portanto ideológico. Quem é que tem direito à produção de imagens?". Ao escrever, havia sido movido pelo desejo de "produzir uma contraideologia de corrosão da ideologia que sustenta a montagem daquela foto" (p. 210).

A foto, então, tem seu sentido aparente confrontado pela recuperação das circunstâncias da montagem da cena (e também pelo afeto que, apesar de tudo, é associado a ela). Ao ganhar forma no poema, que expõe essas circunstâncias, definindo-as como seu objeto de análise, sua

216| LITERATURA CONTEMPORÂNEA: VISADAS ANALÍticas: NA SALA D E A U L A 
lógica é denunciada. Se a fotografia é em algum sentido "documento", o poema e a entrevista sugerem que o que está documentado ali, o que a leitura precisa ver e examinar, é a gramática visual dessa performance de dominação, que o autor remete diretamente às convenções imagéticas da cultura escravocrata, dos retratos de cenas com escravizados montadas por Jean-Baptiste Debret e Johann Moritz Rugendas em seus quadros do século XIX às fotografias de Marc Ferrez no final desse século. De celebração de um triunfo e apresentação dos troféus conquistados, que incluiriam peixe e homens, a cena passa a ser, através da "perversão" realizada pela intromissão do poema, o relato de como "se deu essa derrota", como diz Aleixo (p. 211). Se essas fotografias e quadros foram desde o início "atos perversos", como propõe o autor, ele, em sua própria perversão, busca "outras versões possíveis, outras perversões possíveis" para eles (p. 210), que incluam até o reconhecimento do amor entre as pessoas retratadas (algo impossível entre objetos).

O referente da foto e do poema não desaparece, nem é anulado o status de evidência ou documento que a imagem possa ter. Entretanto, sugere-se que qualquer sentido para a foto é produzido também durante sua interpretação, da qual nem se pode dizer que seja simplesmente posterior ao acontecimento. A "ficção" já estava lá na "origem" - na cena primeira - e, se houve algo que a fotografia documentou, foi essa tentativa de moldar a interpretação do episódio. Se a questão for pensada em diálogo com a narratologia clássica, para a qual é fundamental a pergunta qual a relação entre o evento e a narrativa?, ou, em outra versão, o que veio antes, o evento ou a representação?, fica evidente aqui que no "original" já há uma proposta de sentido, já está presente o desejo de suscitar uma interpretação específica, antecipando o olhar do espectador e intérprete e buscando moldá-lo através da montagem da cena. Em outras palavras, o "evento" já é uma tentativa de narração, e o "conteúdo" do acontecimento já é a busca de uma forma específica para a representação. A suposta anterioridade do evento é desestabilizada porque o evento original que seria registrado já estava cindido, e já imaginava, no momento mesmo em que acontecia, a narração futura. Ao tomar a fotografia, o dono da câmera quis sugerir que estava apenas registrando um evento anterior e externo, que no entanto havia sido preparado por ele apenas para figurar na fotografia, como o poema irá relatar. O que a câmera busca capturar é um original que está, desde sempre, em fuga, desde sempre transbordando, e isso já no instante em que o dedo do dono da câmera dispara. Para Jean-Luc Nancy, em texto sobre outro poema feito a partir de uma fotografia (o poema de Virginie Lalucq sobre a foto de Fortino Sámano tomada instantes antes de seu fuzilamento durante a Revolução Mexicana), "o original de uma fotografia é esse clique de captura e fuga simultâneas", ambas dobradas em si pela imagem (NANCY; LALUCQ, 2012, p. 160). O poema de Aleixo volta a

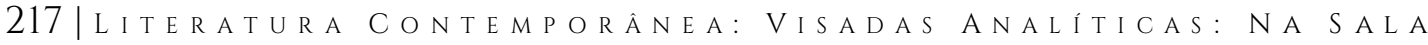
D E A U L A 
desdobrar essa imagem, destacando, em sua leitura, a tentativa de captura, mas também a fuga.

Dado esse quadro, no qual determinados tipos de corpo são expostos, antes ou depois da morte, como troféus, não é incomum que se proponha como solução o alargamento da categoria do humano, incluindo aqueles que teriam sido excluídos dela. Nesse sentido, a rapidez defensiva com que se responde afirmativamente à pergunta incômoda feita por Ricardo Aleixo - "Negros são humanos?" (2018, p. 190) - indica a crença de que o pertencimento à categoria do humano seria uma garantia, um passo indispensável e seguro em direção à extinção da violência racista e da violação dos corpos negros. É compreensível que seja assim, e que o humanismo seja visto como uma solução, justamente porque predomina em muitos espaços a convicção de que a negação da humanidade do outro é uma condição necessária para que ele seja violentado e que a violência extrema é praticada apenas contra o não-humano.

Como no poema "O peixe não segura a mão de ninguém", o que se encontra na obra de Aleixo é algo mais complexo, numa reflexão inquieta e dolorosa a respeito do funcionamento da categoria do humano em culturas racistas. Haveria um extenso trabalho de análise a ser feito de todas as referências ao humano nos muitos poemas do autor que se debruçam sobre a questão; esse, por exemplo, das orelhas do livro Modelos vivos: "tem que ter palavra para ser humano/ tem que ser humano para ter palavra" (2010). Já "Um ano entre os humanos" traz título que lembra memórias etnográficas, mas com a peculiaridade de definir como objeto do estudo não o "selvagem", mas o civilizado e seu olhar. "Você já sabe que pode, mediante exercícios diários, e sob condições especiais, tornar-se mais humano?" - começa o texto para, em seguida, ir acumulando perguntas intempestivas: "O que faz de um humano, humano?"; "Negros são humanos?"; "Você acredita em humanos?"; "Acha que um ciborgue digno desse nome conseguiria viver mais de um ano entre os humanos?"; "Humanos que matam humanos são inumanos, desumanos, humanosferas ou apenas demasiado humanos?"; e, finalmente, na última linha, "Você é humano?" (2018, p. 190-1). Em "Meu negro", o texto publicado logo após "Um ano entre os humanos" na antologia Pesado demais para a ventania, observa-se que "Quando se diz que um homem é um negro o que se quer dizer é que ele é mais negro do que propriamente homem" (p. 194).

Nesses múltiplos relatos etnográficos invertidos, a comunidade exótica, da qual se retorna após uma estada por um tempo determinado para finalmente narrar e traduzir para os pares o que se observou, é a humanidade. Ao delimitar o período passado "entre os humanos", o

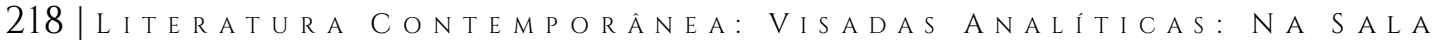
DE A U L A 
enunciador sugere não só a sua exterioridade em relação aos humanos, mas também a dos leitores do texto, aqueles que poderão se interessar pelas descobertas do viajante. Lembrando os experimentos da antropologia dos modernos de Bruno Latour (cf. 2019), trata-se de uma etnografia do olhar e da câmera, não dos fotografados, uma etnografia do humanismo, essa forma de pensar que admite um termo como "humanização" e, portanto, a ideia de hierarquizações entre humanos. Como se vê, a pergunta é não só quem é considerado humano e quem não é, mas também: Quem é mais humano? Quem é humano faz mais tempo? Quem é recém-chegado à humanidade?

O que se depreende desses exames do humanismo não é bem que o humano é uma categoria estável e segura. Também não é que o humano será um refúgio ou garantia contra a violência. Para continuar com essa reflexão, passo agora à leitura de três textos de três autoras diferentes, três questionamentos paralelos da hipótese humanista, que podem nos ajudar a compreender o equívoco que afirma que a exclusão da humanidade é necessária para a prática da violência e que, consequentemente, a inclusão no humano seria uma forma de impedir a violência descomedida. Em seguida, antes de terminar, esboço uma tentativa de explicação para a persistência dessas crenças.

Primeiro, um texto escrito em 1992 pela crítica cultural e ensaísta jamaicana Sylvia Wynter, em reação à absolvição dos policiais que espancaram Rodney King em Los Angeles. Lembrando René Girard, a autora argumenta que a partir dos anos 1960 a expectativa fora que determinado grupo social - jovens negros - pagasse os "custos sacrificiais" necessários para o melhoramento das condições sociais de outros setores da sociedade, partindo do pressuposto de que essas condições não poderiam estar disponíveis para toda a população (cf. WYNTER, 1994). Para justificar a escolha sacrificial, era necessário afirmar, ainda que de maneira ambivalente, tensa e oportunista, a humanidade daqueles cujos direitos eram negados, até para que o espetáculo público de violência pudesse ser apresentado como uma forma de punição, funcionando como ameaça às vítimas (e prêmio para os demais). Só pode haver punição, lembra Wynter, com algum grau de reconhecimento da agência, vontade e consciência dos sujeitos envolvidos. Além disso, a ideia de que a violência antinegro era uma resposta a comportamentos dos próprios negros era necessária para convencer não-negros de seu merecimento, quando esses eram poupados da violência. Por fim, que recursos e direitos não estivessem disponíveis para todos, e que fosse evidente que era assim, estimularia o sentimento de alívio entre aqueles a quem eram concedidos direitos básicos, começando pelo direito à vida.

A definição da negritude como categoria desviante e deslizante dentro da taxonomia humana era nesse sentido uma condição

219| LITERATURA CONTEMPORÂNEA: VISAdas ANALíticas: NA SALA D E A U L A 
imprescindível para o funcionamento do ecossistema racista (WYNTER, 1994, p. 45). Mais do que a ideia de que alguns estão categoricamente excluídos do humano, era fundamental para a manutenção da estrutura social a crença na possibilidade da inclusão e do melhoramento, isto é, a crença na "humanização". O propósito não era exatamente a separação essencialista e definitiva entre incluídos e excluídos, entre o interno e o externo, mas a localização diferenciada de grupos heterogêneos dentro de uma estrutura hierarquizada que se supunha fluida. Seu princípio organizador era a hierarquia e a forma de sua classificação a linearidade teleológica, isto é, a lógica classificatória das categorias raciais. O "ranqueamento genético" estudado por Wynter determina que cada posição esteja fundamentada numa pré-seleção ostensiva de graus superiores e inferiores de valor biológico. Corpos e seres são situados em diferentes posições dentro de uma classificação complexa que contém a promessa (não a possibilidade) de mudança, de forma que o binarismo dentro/fora pouco acrescenta à capacidade analítica.

Nada disso impede, evidentemente, que o racismo se reproduza, e é justamente esse o ponto: a celebração abstrata do humano é capaz de conviver com a violência contra alguns grupos específicos de humanos. Faz-se necessária então uma visão nuançada do pensamento racista que seja capaz inclusive de reconhecer a existência de um humanismo antinegro e racista. Disso resulta também que a afirmação da generalidade do humano não resolverá o problema que precisa ser enfrentado, uma vez que "negro" já está implícito na categoria "humano", como parte de sua lógica classificatória. Recuperando Frantz Fanon, Wynter propõe enfim que a oposição estruturante nesse imaginário não é branco/não-branco, mas homem/não-branco.

Perceber a existência de ranqueamentos étnico-raciais tampouco precisa impedir que se reconheça que a antinegritude opera como uma espécie de grau zero da violência classificatória. Entre o grau mais alto de humanidade e o grau mais baixo, continua Wynter, estão situadas (e buscam se situar) as "categorias intermediárias", seu valor relativo mudando de acordo com a proximidade a um ou outro polo (1994, p. 45). Colocando em outros termos, enquanto o princípio organizador da ordem feudal europeia era o absolutismo de seu arcabouço e de suas divisões, aos quais se atribuía uma origem divina, o princípio organizador do humanismo liberal e moderno é o evolucionismo, manifestado nas categorias hierarquizantes de classe e raça (p. 53). A ideia de melhoramento e a afirmação da disponibilidade da humanização são componentes essenciais dessa ordem, e não gestos críticos a ela. ${ }^{\text {III }}$

VII Para um estudo de como algumas dessas categorias hierarquizantes são utilizadas pela crítica literária brasileira, ver os trabalhos recentes de Anita Martins Rodrigues de Moraes,

220 Literatura Contemporánea: Visadas Analíticas: Na SAla 
No livro Becoming Human: Matter and Meaning in an Antiblack World, a crítica Zakiyyah Iman Jackson, ao recuperar a história da produção do humano em diferentes disciplinas, como a Biologia, a Antropologia, o Direito e a Filosofia, não vai encontrar na categoria exatamente, ou sempre, a exclusão da negritude e a negação da humanidade de pessoas negras (cf. JACKSON, 2020). Em vez disso, descobre um processo complexo e contraditório em que a violência antinegro pôde se apoiar tanto na desumanização quanto na humanização, dependendo da situação. A criação da figura política do escravo nas Américas exigiu, em muitas circunstâncias, a abjeção e criminalização da humanidade do escravizado, precisando para tanto de sua humanização hierarquizada, pois só humanos podem ser criminalizados. Também aqui a proposta é que aquilo que precisa ser entendido e criticado é mais intrincado que uma simples exclusão, que se resolveria com a inclusão, inclusive porque o humano não é uma categoria simples, unitária e homogênea, mas uma noção já racializada e graduada.

\begin{abstract}
Estruturas binárias como "humanização versus desumanização" e "humano versus animal" são insuficientes para entender um regime biopolítico que desenvolve tecnologias de humanização a fim de reconfigurar a negritude como abjeta animalidade humana e estende o reconhecimento humano como parte de um esforço por rebaixar a negritude a "o animal dentro da forma humana". Isso não quer dizer que as expressões e práticas da antinegritude nunca excluam radicalmente os negros da categoria "humano"; em vez disso, a questão é que a inclusão não fornece uma solução confiável visto que, em geral, os negros foram incluídos na (e, pode-se até dizer, dominados pela) "humanidade universal" - mas como a encarnação de dimensões abjetas da humanidade com as quais "o humano" parece estar fundamentalmente e eternamente em guerra. Assim, pessoas negras não têm abrigo, seja quando convidadas a entrar em ou quando trancadas para fora do "humano". (JACKSON, 2020, p. 17)
\end{abstract}

Como pessoas negras têm seus direitos negados e são vítimas de violência tanto quando são excluídas como quando são incluídas, o que é preciso é uma transformação na forma de pensar as diferenças entre os seres, e não apenas a extensão do reconhecimento humano em sua concepção normativa a todos. Não é o caso então de afirmar que

especialmente os textos sobre a noção de humanização em Antonio Candido (MORAES, 2016 e 2017, além do manuscrito inédito Contornos humanos: Primitivos, rústicos e civilizados em Antonio Candido). Também seria possível revisitar aqui a bibliografia que pensou a relação entre melhoramento, humanização e sala de aula. O ensino existe para nos tornar mais humanos? - é uma antiga questão pedagógica. Terá que ficar para outra ocasião, ou para outras pessoas.

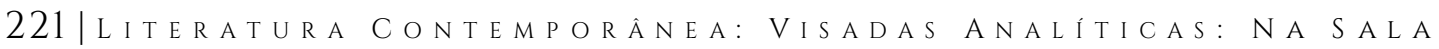


desumanizar é ruim, enquanto humanizar seria bom, pois o que precisa ser estudado e criticado é a própria ética e política da humanização.

Por último, o ensaio "Humanism: A Critique", da filósofa Kate Manne (2016), sobre convergências entre humanismo e misoginia. No artigo, ao estudar episódios de misoginia homicida, a autora observa que nesses casos não havia sido necessário primeiro negar a humanidade das vítimas para que só depois fosse praticada violência contra elas. A dinâmica parece na verdade mais próxima do movimento contrário: era ao perceberem que mulheres eram como eles, com vontades, desejos e agência, que os agressores, indignados, atacavam.

A reivindicação humanista da extensão da humanidade ao outro aqui seria impotente, pois o problema do misógino é justamente com o poder que ele considera que as mulheres já possuem, isto é, com o fato de que elas também são humanas. Enquanto isso, o paradigma humanista pressupõe que é raro que seres humanos maltratem e violentem seus pares, precisando, para que isso aconteça, de uma história convincente e intrincada como é a narrativa da desumanização (p. 407). Em críticas humanistas à injustiça, que colocam sujeitos privilegiados no centro do debate, por vezes parece que

\footnotetext{
a tarefa na luta para acabar com a opressão seria simplesmente abrir os braços e abraçar a humanidade, ou talvez simplesmente a senciência, do resto de nós. Essa imagem situa o agente (supostamente relevante) dentro do mundo, mas se esquece de toda a estrutura vertical que o mundo contém - isto é, de todos os bastiões de privilégio que precisariam ser desmantelados para alcançar a justiça social. (p. 406)
}

Não surpreende que essas fortalezas sejam defendidas energicamente e que muitos estejam investidos em sua preservação, fazendo uso da noção de meritocracia ou da afirmação da neutralidade da visão de mundo dominante. É inclusive essa perspectiva que permitirá que o desmonte de estruturas e práticas que sustentam privilégios seja vivido como uma injustiça para os privilegiados (p. 406-7), explicando o backlash que frequentemente ocorre após o fortalecimento de grupos subalternos, como ocorre com o ressurgimento energizado de ideários e práticas machistas, racistas e homofóbicas. "Por que", pergunta Manne um pouco desconcertada, "se imagina que o reconhecimento da humanidade de membros de classes sociais subordinadas - no sentido de reconhecer sua capacidade para a excelência humana - seria visto como uma notícia 
uniformemente boa para membros de grupos até então dominantes?" (p. 406).

A reflexão de Manne apresenta um desafio para alguns hábitos comuns ao pensamento humanista. Ela constata que vítimas muitas vezes são vistas como humanas nos textos de seus agressores misóginos, e que é o reconhecimento dessa agência - que recusa abordagens indesejadas, por exemplo - que leva à agressão. Nesse contexto, deixa de ser eficaz a posição que sustenta que bastaria reconhecermos que os outros são basicamente como "nós" (desejam as mesmas coisas, têm as mesmas necessidades, etc.) para que tudo se resolvesse. Além disso, passa a parecer duvidoso o pressuposto de que esse "nós" seria bondoso.

A categoria analítica necessária para entender a misoginia, sugere Manne, não é o inumano, mas um conjunto heterogêneo que inclui a inimiga, a rival, a usurpadora, a traidora, a insubordinada (o sujeito menor que se insurge contra sua posição no campo) e a ingrata (acusação fundamental para entender o imaginário misógino, dada a expectativa da doação da mulher ao homem). Em contraste, a violência que atinge animais ou não-humanos é engendrada apelando a outra classe de imagens e justificativas, com os alvos vistos como caça ou ameaça (p. 404). Além disso, pensando nos objetivos de ofensas bestializantes, Manne observa que essas

depreciações dificilmente seriam consideradas apropriadas caso se tratasse de fato de animais não-humanos, que não poderiam compreender o insulto, nem seriam reprimidos de modo eficaz ao verem seu status como não-humanos corretamente identificado. Isso requereria compreensão humana, sem falar de um status humano incipiente do qual ser rebaixado. Não há vergonha em ser chamado de rato se você de fato é um. (p. 412)

Uma possível explicação para a atração gerada pela hipótese humanista, que chegou a se tornar um pilar do nosso senso comum, é o aspecto autocongratulatório do movimento discursivo condescendente que afirma que o outro também é humano. ${ }^{\mathrm{VIII}} \mathrm{O}$ resultado desse gesto será sempre um projeto expansionista e teleológico: é preciso estender o imaginário humanista a quem (ainda) não o tem. Outro motivo para a ubiquidade da fantasia é o poder retórico e político da afirmação da própria generalidade, que, dada sua obviedade neutra, até dispensaria justificativas. (Quem seria contrário à humanização?) Tampouco há

\footnotetext{
VIII Na versão desse argumento que aparece nos estudos literários, especialmente quando esses se veem diante de produções culturais marginais (literatura periférica, práticas discursivas indígenas, formas de oralidade, etc.), a sugestão é que essas práticas também são literatura.
}

223 literatura Contemporânea: Visadas Analíticas: Na SAla 
necessidade de autocrítica, o problema estando resolvido já na origem; a própria formulação da hipótese humanista já seria a solução. A falta estaria sempre em sua ausência, nunca nela mesma.

As considerações de Wynter, Jackson e Manne glosadas rapidamente aqui exigem, junto às perguntas incômodas que aparecem nos poemas de Ricardo Aleixo, que o pensamento humanista saia em busca de soluções que não estão já contidas nele, sugerindo que o humanismo pode não ser a solução para os impasses que ele gerou. A categoria do humano e a afirmação da generalidade da humanidade não têm como acabar com as formas variadas de opressão que enfrentamos, porque é parte fundamental do conceito de humano sua diferença em relação a grupos subalternos. Numa formulação sintética (e terrível) do impasse, sugerida por Frank Wilderson no livro Afropessimism, o contrário de negro é humano (e não branco) (cf. WILDERSON, 2020). A inflexão provocada por gestos como esses é decisiva. Com ela, já não faz sentido dizer que um dia todos seremos humanos, sem distinção de raça, gênero, classe ou sexualidade, como não se sustenta a designação do humano como horizonte político. Na própria ideia de humano, afinal, já estão presentes o escravo, o negro, a mulher e o selvagem, e uma sombra repousa para sempre sobre ela.

\section{Referências bibliográficas}

AleIXO, Ricardo. Modelos vivos. Belo Horizonte: Crisália, 2010.

ALEIXO, Ricardo. “O peixe não segura a mão de ninguém". Jaguadarte: posse de Ricardo Aleixo. Belo Horizonte, 28 out. 2007. Disponível em http://jaguadarte.blogspot.com/2007/10/no-fico.html.

AleIXO, Ricardo. Pesado demais para a ventania. São Paulo: Todavia, 2018.

GuHA, Ranajit. "The Prose of Counter-insurgency". In: GUHA, Ranajit; SPIVAK, Gayatri (orgs.). Selected Subaltern Studies. Delhi: Oxford University Press, 1988, p. 45-86.

JACKSON, Zakiyyah Iman. Becoming Human: Matter and Meaning in an Antiblack World. Nova York: New York University Press, 2020.

LATOUR, Bruno. Investigação sobre os modos de existência: uma antropologia dos modernos. Tradução de Alexandre Agabiti Fernandez. Petrópolis: Vozes, 2019.

Manne, Kate. "Humanism: A Critique." Social Theory and Practice. Charlottesville, v. 42, n. 2, p. 389-415, 2016.

MORAES, Anita Martins Rodrigues de. "A função da literatura nos trópicos: notas sobre as premissas evolucionistas de Antonio Candido". Cerrados. Brasília, DF, n. 45, ano 26, p. 41-54, 2017. 
MORAES, Anita Martins Rodrigues de. "Notas sobre humanos e animais em Antonio Candido". Rivista Letterature d'America. Roma, v. 160, p. 71-92, 2016.

NANCY, Jean-Luc; LALUCQ, Virginie. Fortino Sámano: (Les debordements du poeme/ The Overflowing of the Poem). Tradução de Sylvain Gallais e Cynthia Hogue. Richmond: Omnidawn, 2012.

PATTERSON, Orlando. Escravidão e morte social: um estudo comparativo. Tradução de Fábio Duarte Joly. São Paulo: Edusp, 2008.

PereIRA, Edimilson de Almeida. Poesia + (Antologia 1985-2019). São Paulo: 34, 2019.

SANTOS, Luciany Aparecida Alves. Modelos vivos: poesia e performance de Ricardo Aleixo (em) um exercício crítico de literatura contemporânea. Tese de Doutorado. João Pessoa: Universidade Federal da Paraíba, 2015.

WILDERSON III, Frank B. Afropessimism. Nova York: Liveright, 2020.

WYNTER, Sylvia. “No Humans Involved: An Open Letter to My Colleagues". Forum NHI: Knowledge for the 21st Century. [S. l.], v. 1, n. 1, p. 42-70, 1994.

Marcos Natali possui mestrado e doutorado em Literatura Comparada pela Universidade de Chicago. É professor livre-docente de Teoria Literária e Literatura Comparada na Universidade de São Paulo e publicou os livros A literatura em questão: Sobre a responsabilidade da instituição literária (Ed. UNICAMP, 2020) e A política da nostalgia: Um estudo das formas do passado (Nankin, 2006) e artigos sobre Roberto Bolaño, Jacques Derrida, José María Arguedas, Mario Bellatin, Marília Garcia, Ana Martins Marques e o racismo em Monteiro Lobato, além do capítulo sobre a América Latina na Cambridge History of Postcolonial Literature. Com Marcos Siscar, organizou o volume Margens da democracia: a literatura e a questão da diferença (Ed. UNICAMP / Edusp, 2015). Contato: $\underline{\text { mpnatali@usp.br }}$

ORCiD: https:/ / orcid.org/0000-0003-4609-5431

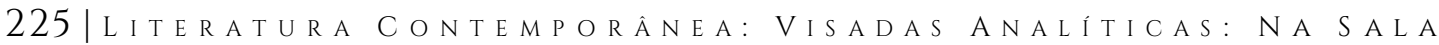

